\title{
Breeding for Improved Disease Resistance in Organic Farming - Possibilities and Constraints
}

\author{
By Ulf Magnusson
}

Department of Obstetrics and Gynaecology, Faculty of Veterinary Medicine, Centre for Reproductive Biology in Uppsala (CRU), S-750 07 Uppsala.

\begin{abstract}
Lowered incidences of disease may be reached in several ways: management and rearing measures, vaccination programmes and preventive medications as well as breeding for improved disease resistance. Here the focus is on breeding for improved resistance to infectious diseases. In comparison to conventional farming, one has to acknowledge that the spectrum of diseases in animals reared under organic conditions is different and that the proportion of the breeding stock of animals in organic farming is considerably smaller. There are at least four different approaches that may be used in breeding towards resistance to infectious diseases. The most obvious is to record disease incidence in the progeny and select those parents that produce the progeny with the lowest incidences of disease. Another approach is to use breeders possessing certain major histocompatibility complex antigens suggested being associated with resistance to certain infections. A third approach is to analyse the heritability of a set of immune functions or related traits crucial for resistance to infections and then use the traits with high heritability in breeding programmes. Finally, one may genetically select animals for high immune response using an index that combines estimated breeding values for several immunological traits. Examples of these various approaches are given and the feasibility for using these in organic farming are discussed.
\end{abstract}

Organic farming, disease resistance, animal health, ethics, breeding, infections, immunology

\section{Introduction}

Healthy animals are desired in all kinds of animal farming. The basis for this desire is formed by ethical, economical as well as public health components. Some of the hallmarks in organic animal farming are high wellbeing standards, in which freedom from disease plays a major role, and a low usage of drugs such as antibiotics (e.g. $K R A V, 2000)$. Hence, to have a low disease incidence in organic farming is truly an issue. There are several avenues towards a lowered incidence of disease: management and rearing measures, vaccination programmes and preventive medications as well as breeding for improved disease resistance. The current review will deal with the latter approach with a focus on infectious diseases. However, the principles discussed here may also apply for other kinds of diseases.

Firstly, one have to acknowledge that the spectrum of diseases in animals reared under organic conditions may differ from that in animals reared in conventional farming systems (Hansson et al. 2000). Secondly, the stock of animals in organic farming is considerably smaller than that of animals in conventional farming thereby making it very difficult to have special breeding populations for organic farming. However, regarding records on disease in the animal stock that may be used in breeding programs, the Nordic countries are extremely 
well off because of the national computerised record systems, (e.g., National Board of Agriculture, 2000)

\section{Approaches for breeding towards resistance to infectious diseases}

Breeding directly for resistance to infectious diseases

The most obvious is to record disease incidence in the progeny and select those parents that produce the progeny with the lowest incidence of disease. Indeed, the heritability has been shown to be high enough for some diseases to permit such a direct selection (Lundeheim, 1988). An example of this approach is the inclusion of the predisposition to mastitis in the cattle breeding programs in Sweden. The heritability for clinical and subclinical mastitis in Swedish dairy cattle is 0.02 and 0.15 , respectively (Mark et al. 2000). However, it is likely that the these heritability figures cannot be transferred directly to animals in organic farming systems since one may assume that there is an interaction between genotype and production system.

A slightly different approach to increase animal health is of course to increase the weight of disease resistance in the progeny testing on the benefit of production traits. Currently resistance to mastitis in the testing of Swedish bulls is given a value of 0.4 in the total merit index, as compared to milk protein production which is given a value of 1.0.

The feasibility of this approach in organic farming is limited by the small breeding stock in organic farming and that one has to identify and focus on one or may be two diseases of paramount importance. Possibly one such disease complex is intestinal helminths in sheep and indeed a heratibility of 0.2 to 0.4 of wormegg counts in feaces in different sheep-lines has been demonstrated suggesting a genetic control of resistance to helminths in sheep (Windon, 1996).
Using breeding stock possessing certain major histocompatibility complex (MHC) antigens Another approach is to use a breeding stock possessing certain major histocompatibility complex (MHC) antigens, which are involved in the regulation of the immune response. The classical example of this approach is that chickens possessing the B 2 haplotype are resistant to Marek's disease (Hepkema et al. 1993). Otherwise, attempts to use MHC antigens as markers for genetic resistance to infections have been contradictory (Hill, 1998).

\section{Including immune function traits with high heritability in breeding programmes}

A third approach is to analyse the heritability for a set of immune functions or related traits crucial for resistance to infections. An example of this is the discovery of a very high heratibility for the number of circulating neutrophils in the pig (Edfors-Lilja et al. 1994). Such traits, i.e. those important for resistance to infections with high heritability, may then be included as selection criteria in breeding programmes.

\section{Genetic selection for animals with a high combined immune response}

Finally, one may genetically select animals for high immune response using an index that combines estimated breeding values for several immunological traits, e.g., Mallard et al. 1992. In a pig heard such low and high responder lines (LIR and HIR, respectively) have been maintained for several generations. In a challenge experiment with Mycoplasma hyopneumonie the HIR pigs had a better protection against polyserositis but suffered more from arthritis (Magnusson et al. 1998). Moreover, the HIR pigs responded better to vaccination against Actinobacillus pleuropneumonie, i.e., an indirect way to improved resistance (Magnusson et al. 1997). This approach needs an establishment of certain breeding lines. 


\section{Conclusion}

Even though one may hypothesise about several possible approaches for breeding for improved resistance to infections in organic farming as outlined in this review, there are also several constraints. Before starting this kind of breeding a thorough analysis has to be done of such issues as: should one use the breeding stock in conventional farming or should one use certain breeding-lines just in organic farming? Which are the diseases in organic animal husbandry that are the most important? How should the balance between disease resistance and productivity be within the breeding in organic farming?

These and similar issues are true challenges for veterinarians and animal breeders towards improved resistance to disease in organic farming.

\section{Acknowledgement}

Dr. Kjell Johansson, Interbull, Uppsala is acknowledged for invaluable comments during the preparation of this manuscript.

\section{References}

Edfors-Lilja I, Wattrang E, Magnusson U, Fossum C: Genetic variation in parameters reflecting immune competence of swine. Vet. Immunol. Immunopath. 1994, 40, 1-16

Hansson I, Hamilton C, Ekman T, Forslund K: Carcass quality in certified organic production compared with conventional livestock production. J. Vet. Med. B. 2000, 47, 111-120.

Hill AVS: The immunogenetics of human infectious diseases. Ann. Rev. Immunol. 1998, 16, 593-617.

Hepkema BG, Blankert JJ, Albers GA, Tilanus $M G$, Egberts E, Zijpp AJ van der, Hensen EJ: Mapping of susceptibility to Marek's disease within the major histocompatibility (B) complex by refined typing of White Leghorn chickens. Anim. Genet. 1993, 24(4), 283-287

$K R A V$ : Objectives of Organic farming. 2000, http://www.krav.se/pl/malpl.htm

Lundeheim N: Health disorders and growth performance at a Swedish pig progeny testing station. 1988, Acta. Agric. Scand. 38, 77-88.

Magnusson U, Mallard BA, Bosse JT, Kennedy BW,
Wilkie BN: Antibody response to Actinobacillus pleuropneumoniae antigens after vaccination of pigs bred for high and low immune response. Vaccine, 1997, 15, 997-1000.

Magnusson U, Wilkie BN, Mallard BA, Rosendal S, Kennedy $B W$ : Mycoplasma hyorhinis infection of pigs selectively bred for high and low immune response. Vet. Immunol. Immunopath. 1998, 61, 83-95.

Mallard BA, Wilkie BN, Kennedy BW, Quinton M: Use of estimated breeding values in a selection index to breed Yorkshire pigs for high and low immune and resistance factors. Anim. Biotech., 1992, 3, 257-280.

Mark T, Fikse WF, Sigurdsson A, Philipsson J: Feasibility of international genetic evaluations of dairy sires for somatic cell count and clinical mastitis. Interbull Bulletin, 2000, 25, 154-162.

Windon $R G$ : Genetic control of resistance to helminths in sheep. Vet. Immunol. Immunopath. 1996, 54 (1-4), 245-54.

National Board of Agriculture: Vet@ - a tool for better animal health. 2000, Jönköping, Sweden.

\section{Sammanfattning}

Minskad sjukdomsincidens kan nås på flera sett: genom hur djuren hålls, vaccinationsprogram, förebyggande medicinering och avel för förbättrade motståndskraft mot sjukdom. Denna artikel fokuserar på avel för ökad motståndskraft mot infektionssjukdomar. I jämförelse med konventionell djurhållning måste man vara medveten om att sjukdomsspektrumet i ekologisk djurhållning är annorlunda och att avelsmaterialet är betydligt mindre. Det finns åtminstone fyra olika vägar att gå för att avla för motståndskraft mot infektiösa sjukdomar. Den mest självklara är att notera sjukdomsincidens hos avkommor och välja de föräldrar som ger upphov till den lägsta sjukdomsincidensen. En annan väg är att använda avelsdjur som har särskilda transplantationsantigener som anses förknippade med resistens mot särskilda infektioner. En tredje väg är att analysera en räcka immunologiska funktioner som är viktiga för resistens mot infektioner med avseende på deras arvbarhet och sedan använda de funktioner med hög arvbarhet $\mathrm{i}$ avelsprogram. Slutligen kan man genetiskt selektera för djur med högt immunsvar baserat på ett index som kombinerar uppskattade avelsvärden för flera immunologiska funktioner. Exempel på dessa olika vägar ges och deras användbarhet i ekologisk djurhållning diskuteras. 